\title{
TEMPERAMENT AND EMOTIONAL INTELLIGENCE IN THE CASE OF SPORTS MANAGERS
}

\section{Radu PREDOIU ${ }^{1}$, Eduard Ștefan DUMITRU ${ }^{1}$, Alexandra PREDOIU ${ }^{1 *}$, Nicoleta GHEORGHIȚA ${ }^{2}$, Ștefan-Dănut TUDORANCEA ${ }^{1}$}

\footnotetext{
${ }^{1}$ National University of Physical Education and Sport, Faculty of Physical Education and Sport, Bucharest, Romania

${ }^{2}$ University of Bucharest, Faculty of Foreign Languages and Literatures, Bucharest, Romania *Corresponding author: alexandra.predoiu@yahoo.com
}

https://doi.org/10.35189/dpeskj.2021.60.2.9

\begin{abstract}
Emotional intelligence (EI) and temperamental characteristics are essential aspects for managers to develop human potential. A total of 50 sports managers $(25$ currently employed and 25 future sports managers) took part in the study, completing the Questionnaire for Self-Determination and Measurement of Emotional Intelligence, as well as the Temperament Self-Assessment Questionnaire, based on Jung's typology (introversion, extraversion and four psychological functions: sensation-intuition and thinking-feeling). Through the t test for independent samples, we found significant differences between the two groups of participants, in the case of three factors of emotional intelligence but also in the overall score of EI. In other words, managers in sports organizations recognise and control significantly better their own emotions and mobilise their resources to a higher level to achieve a goal compared to future sports managers. At the same time, we highlighted significant differences in the case of extraverted sensing (ES) temperamental type. Experienced sports managers are more open, sociable and interpret information in a significantly different way compared to future sports managers. Specifically, managers in sports organizations rely significantly more, in the interpretation of information, on direct and concrete experiences, on the five senses (relating more strongly to external stimuli), and less on intuition (in which case, the interpretation of information occurs in the absence of concrete details). The findings of our study provide future sports managers with valuable information about emotional intelligence factors and temperamental characteristics specific to managers with experience in the field.
\end{abstract}

Keywords: sports manager, emotional intelligence, temperament.

\section{Introduction}

Management and leadership are required to achieve organizational sport goals. "Managers are often leaders, not all leaders are necessarily managers" (Ibrahim, 2016, p. 74). It is essential for sports managers to have an academic background because, as professionals, they need to have some information about business administration, organizations, managerial psychology but also about the particularities of sport products.

Sports organizations are defined as multicultural entities when customers or staff belong to various cultures (Girginov et al., 2006). Therefore, it is very important for sports managers to develop appropriate cross-cultural skills (various cultures have different value orientations) in order to run marketing campaigns, international events or sponsorship deals.

Over time, the motivation of sports managers has been "regarded" differently. For example, according to some researchers, sports managers maximise efficiency in the pursuit of nonprofit purposes (they are oriented towards satisfaction rather than profit), while others highlight that sports managers are profit maximisers (see Barros \& Lucas, 2001). We also 
mention an intermediate position (Vrooman, 2000) - sports managers jointly maximise both satisfaction and profit. While East European sport management largely means to ensure the planned functioning of the sport system as a whole (see Girginov et al., 2006), the important concerns of North Americans are related to providing services in the most cost-effective way (Soucie, 1994).

An activity to which sports managers pay special attention consists in ensuring good infrastructure for sports facilities, which is a prerequisite for using the instrumental value of sport (Hoekman et al., 2019). This managerial approach that takes into account sport preparation (involving organization, planning, leadership and assessments) becomes the key to the successful training of athletes (Teodorescu \& Urzeală, 2013).

Horch and Schütte (2003) described the main activities and competencies needed by sports managers in German sports federations and clubs. After investigating almost 200 sports managers, the authors have found that their main activities are represented by: leading and managing (top management functions); coaching tasks combined with lobbying for external support; communication (and information); social contacts and problem solving; administration (and management of clients and central resources), while their competencies are: resource management (gaining clients/members, developing new products, new offers); financing, accounting, law (costs, tax laws); facility management (public relations, advertising, event management); service offers (sport science); information technology; marketing for professional sport (sponsoring, personal and human resource management). Figure 1 shows the importance of different activities for the sports manager job (top - very important; down - less important).

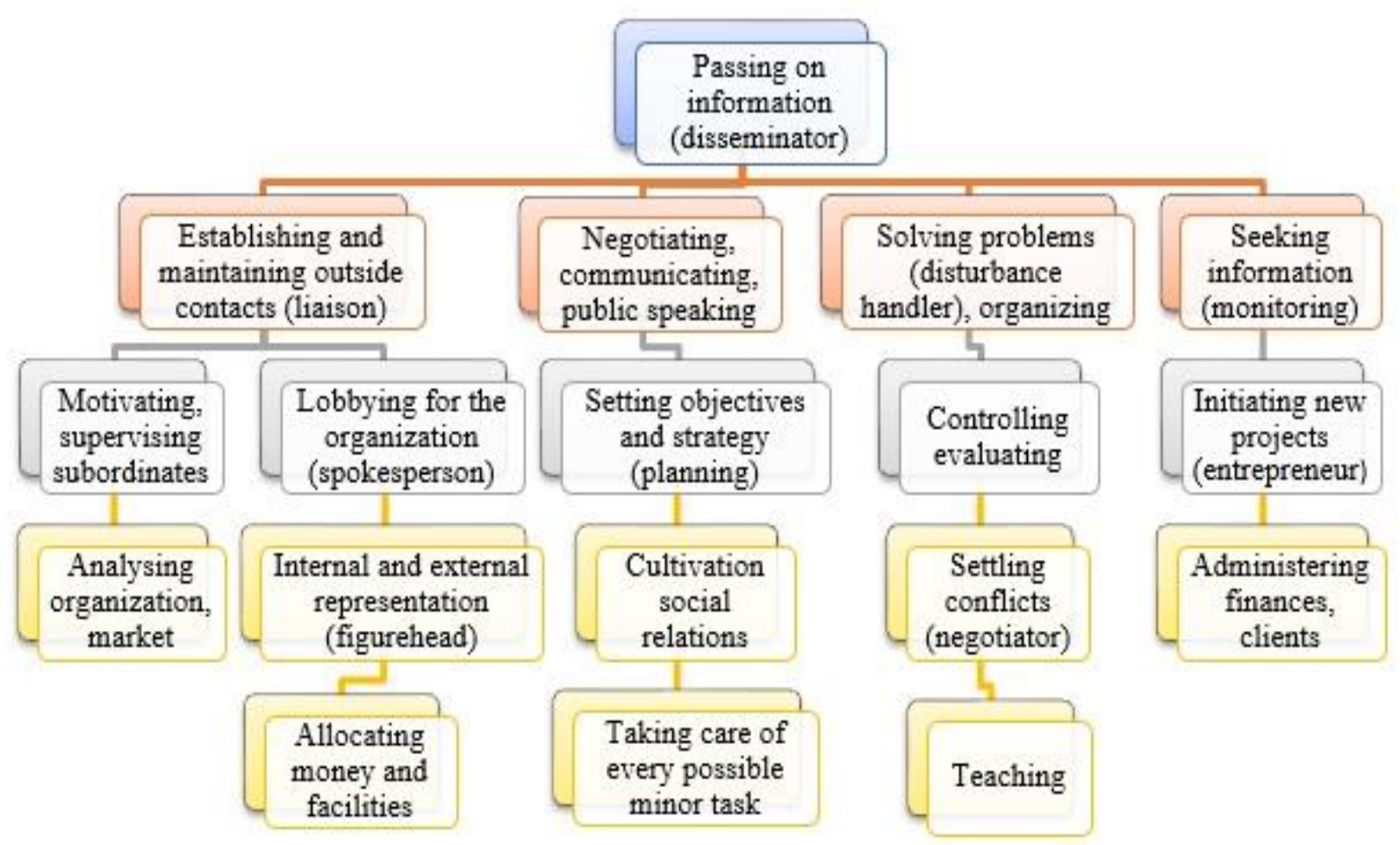

Figure 1. Ten important activities (top down) for sports managers

(Horch \& Schütte, 2003) 
Even if women have demonstrated managerial and leadership skills, being as successful as men in this field, and the number of female managers has increased over time (Ayman et al., 2009), women are still underrepresented in management positions (Koca \& Öztürk, 2015; Mostafa, 2003). A possible explanation for this might be, according to Martell et al. (1998) and Schein (2007), that management-related traits are (commonly) perceived as masculine. Considering managerial roles in sport, Messner (2002) talks about competitiveness and physical and mental toughness, which represent rather masculine attributes. Stoker et al. (2012) claim that generally employees prefer a male manager (instead of a female manager).

Efficient managers develop the emotional intelligence (EI) of their employees, playing a catalytic role (Chopra \& Kanji, 2010). Emotional intelligence was developed from Gardner's multiple intelligences, being a combination of intrapersonal and interpersonal emotional abilities. Mayer and Salovey's model of EI identifies four branches: perception of emotions, understanding emotions, management of emotions and integration of emotions in thinking (which serves for a better understanding of the other's perspective), while Goleman discusses self-awareness, self-management, relationship management (empathy) and social awareness (see Pearson \& Weinberg, 2017).

The emotions that a person experiences when working best reflect the quality of their professional life. A leader must generate positive emotional states, motivate employees/ team members, receive and give feedback (even critical feedback) in order to positively influence success in the workplace (Hacker, 2003). The emotional skills of sports club managers facilitate positive relationships with others (coaches, athletes, parents, etc).

Temperament, as a subsystem of personality, reflects the dynamic-energetic aspect of a person. Temperament is the subset of personality that has the strongest genetic determination, being the most accessible to knowledge, the most easily ascertainable component of personality (Mitrache \& Predoiu, 2016). Impulsivity, combative spirit, patience, calm, introversion, extraversion, good mood, etc. are temperamental traits that inevitably leave their mark on the efficiency of sports managers (Dumitru, 2021).

Investigating 15 top coaches from various sports - coaches who held (over time) or are currently holding very important managerial positions in sports federations or clubs (presidents, general managers, vice presidents, directors), Predoiu et al. (2020) highlight the following personality traits: high conscientiousness and agreeableness, low neuroticism, delegation and decision-making ability, leadership ability and internal locus of control. Another study (Macra-Osorhean et al., 2011) conducted on 200 Romanian sports managers has revealed that they are characterised by the tendency to avoid monotony, a high level of sociability and social desirability, inhibition of aggression and guilt. It is particularly important in performance sports activity (for sports managers also) to foster, develop desirable and adaptive behavior and to suppress undesirable behavior. "The regulation and self-regulation of behavior implies the synergic action of all components of the human psychological system" (Pelin et al., 2018).

Considering the temperament of future sports managers, the literature describes the importance of two classic temperaments, sanguine and phlegmatic, which are emotionally stable temperamental types, being recommended for holding managerial positions (Stănescu et al., 2016). In the present study, temperament is investigated starting from a different typology, namely Jung's typology, which proposes two main orientations: introversion and 
extraversion as well as four psychological functions: sensation-intuition and thinking-feeling (Minulescu, 2012). Overall, there are eight temperamental types where: IT - introverted thinking; ET - extraverted thinking; IF - introverted feeling; EF - extraverted feeling; IS introverted sensing (sensation); ES - extraverted sensing (sensation); IN - introverted intuition; EN - extraverted intuition. If extraverts are more sociable, communicative and adapt more easily to the external environment, introverts are more interested in their inner world (their own thoughts and feelings), prefer loneliness or smaller social groups and are hesitant in new situations.

The four psychological functions are described by Joyce (2010) as follows:

- sensation-intuition functions refer to how people interpret information. Intuition is based on vague ideas (without concrete details) and works as a fast way to assimilate information and quickly integrate it into previous experiences. Sensation greatly relies on the five basic senses and is strongly related to external stimuli, to direct and concrete experiences;

- thinking-feeling functions influence assessment and decision-making. People who rely on feeling tend to make decisions based on their own values and norms, depending on what they like or dislike. Instead, people who prefer the thinking function carefully analyse the details, rely on logic and try to make objective decisions.

The aim of this research is to investigate the level of emotional intelligence and the temperamental characteristics of experienced sports managers and future sports managers.

\section{Objectives}

- Highlighting the level of emotional intelligence of managers working in sports organizations and that of future sports managers;

- Knowing the dominant type of temperament of both current sports managers and future sports managers.

\section{Hypotheses}

H1: There are significant differences between the level of emotional intelligence of current sports managers and that of future sports managers.

$H 2$ : The investigation of temperament reveals significant differences between experienced sports managers and future sports managers.

\section{Methodology}

\section{Participants}

Study participants were 25 sports managers from Bucharest (presidents, vice presidents, directors, deputy directors, general managers of sports clubs and federations), with an experience of at least 3 years (aged between 27 and 60 years), and 25 future sports managers 
attending the programme "Management and Marketing in Sports Structures, Activities and Events" at the National University of Physical Education and Sport in Bucharest. In each group, there were about $70 \%$ men.

\section{Instruments}

To investigate emotional intelligence (EI), the Questionnaire for Self-Determination and Measurement of Emotional Intelligence (Gatjens-Reuter \& Behrens, 1999) was used. The questionnaire provides information on five factors of emotional intelligence: F1 Recognition of one's emotions; F2 - Control, intelligent manipulation of emotions; F3 - Inner motivation and productive use of emotions; F4 - Empathy; F5 - Interpersonal relationships. The maximum score for each factor is 20. The total score for EI is the sum of the five components (factors). The questionnaire has 20 questions (4 items for each factor of emotional intelligence), and participants were asked to assess the extent to which each statement was appropriate for them. The five response options were: 1 - to a very small extent; 2 - to a small extent; 3 - to a relative extent; 4 - to a large extent; 5 - to a very large extent. Participants had only one response option that best corresponded to their psychobehavioural reactions.

To investigate temperament, the Temperament Self-Assessment Questionnaire (Minulescu, 2012) was used, based on Jung's typology. Instructions: "You will find four situations that may arise in everyday life. There are eight ways to respond (or eight possible reactions) to each situation. You must assess to what extent the reactions are characteristic of you. Write the number that corresponds to your assessment for each item, using the following scale: $1=$ Never, $2=$ Very rarely, $3=$ Sometimes, $4=$ Often, $5=$ Always.

\section{Procedure}

The study was conducted between March and April 2021. The two questionnaires (to investigate emotional intelligence and temperament) were applied online via Google Forms by two of the authors of this study. We specify that the ethical principles were ensured: the informed consent was obtained, participants could withdraw from the study at any time, data were treated confidentially and anonymity was ensured.

\section{Quasi-experimental design}

Dependent variables are represented by the participants' results obtained with the help of instruments used in the research (to assess EI and Temperament), while the inclusion of managers in one of the two groups (current or future sports managers) plays the role of the independent variable. 


\section{Results}

In a first stage, the results obtained by current and future sports managers were investigated in terms of emotional intelligence (Table 1).

Table 1. Descriptive statistics: current and future sports managers - Emotional Intelligence

\begin{tabular}{lcccccccccccccc}
\hline Factors & \multicolumn{2}{c}{ Min } & \multicolumn{2}{c}{ Max } & \multicolumn{2}{c}{ Range } & \multicolumn{2}{c}{ Mean } & \multicolumn{2}{c}{$\begin{array}{c}\text { Std. } \\
\text { Deviation }\end{array}$} & \multicolumn{2}{c}{ Std. Error } & \multicolumn{2}{c}{$\begin{array}{c}\text { Coef. of } \\
\text { variation }\end{array}$} \\
\hline & C & FM & C & FM & C & FM & C & FM & C & FM & C & FM & C & FM \\
F1 & 13 & 13 & 20 & 19 & 7 & 6 & 17.72 & 16.56 & 1.76 & 1.75 & 0.35 & 0.35 & 0.09 & 0.10 \\
F2 & 10 & 10 & 20 & 10 & 10 & 10 & 15.56 & 14.16 & 2.34 & 2.47 & 0.46 & 0.49 & 0.15 & 0.17 \\
F3 & 13 & 10 & 20 & 20 & 7 & 10 & 17.40 & 16 & 1.87 & 2.84 & 0.37 & 0.56 & 0.10 & 0.17 \\
F4 & 11 & 13 & 20 & 20 & 9 & 7 & 16.20 & 16.84 & 2.64 & 2.28 & 0.52 & 0.45 & 0.16 & 0.13 \\
F5 & 9 & 12 & 20 & 20 & 11 & 8 & 16.28 & 16.56 & 2.77 & 2.34 & 0.55 & 0.46 & 0.17 & 0.15 \\
EI & 66 & 64 & 94 & 97 & 28 & 33 & 83.16 & 79.12 & 6.85 & 7.85 & 1.37 & 1.57 & 0.08 & 0.09 \\
\hline
\end{tabular}

Note. C: Current sports managers; FM: Future sports managers; EI: Total emotional intelligence score; F1: Recognition of one's emotions; F2: Control, intelligent manipulation of emotions; F3: Inner motivation and productive use of emotions; F4: Empathy; F5: Interpersonal relationships.

Taking into account the norms, current sports managers working in sports organizations have a very high level of emotional intelligence $(M=83.16)$, while future sports managers show a good level of EI $(M=79.12)$.

To verify whether there were significant differences between the two groups (current and future sports managers) in terms of emotional intelligence, the $t$ test for two independent samples was used (Table 2).

Table 2. Inferential statistics - Emotional Intelligence

\begin{tabular}{|c|c|c|c|c|c|c|c|c|c|c|c|c|}
\hline \multirow[t]{2}{*}{ Factors } & \multicolumn{2}{|c|}{ Skewness $<|1|$} & \multicolumn{2}{|r|}{ F test } & \multicolumn{4}{|c|}{ t test - Equal variances } & \multicolumn{4}{|c|}{ t test - Unequal variances } \\
\hline & C & FM & $\mathrm{F}$ & F critical & $\mathbf{p}$ & $\mathbf{t}$ & df & g & $\mathbf{p}$ & $\mathrm{t}$ & df & $\mathbf{g}$ \\
\hline F1 & -0.71 & -0.05 & & $1<1.98$ & 0.012 & 2.32 & 48 & 0.66 & & & & \\
\hline F2 & -0.07 & 0.03 & & $9>0.50$ & & & & & 0.022 & 2.05 & 48 & 0.58 \\
\hline F3 & -0.76 & -0.59 & & $3<0.50$ & 0.022 & 2.05 & 48 & 0.58 & & & & \\
\hline F4 & -0.29 & -0.26 & & $4<1.98$ & 0.182 & -0.91 & 48 & 0.25 & & & & \\
\hline F5 & -0.83 & 0.26 & & $0<1.98$ & 0.163 & 0.99 & 48 & 0.10 & & & & \\
\hline EI & -0.94 & 0.46 & & $6>0.50$ & & & & & 0.029 & 1.93 & 48 & 0.54 \\
\hline
\end{tabular}

Note. C: Current sports managers; FM: Future sports managers; EI: Total emotional intelligence score.

As the skewness coefficient (in absolute value) is less than 1 (Table 2), the condition requiring a normal distribution is met.

We highlighted significant differences between the two groups of participants for three factors of EI: Recognition of one's emotions ( $M_{\text {Current sports managers }}=17.72, M_{\text {Future sports managers }}=$ 16.56), Control, intelligent manipulation of emotions $\left(M_{\text {Current sports managers }}=15.56, M_{\text {Future sports }}\right.$ managers $=14.16)$, Inner motivation and productive use of emotions ( $M_{\text {Current sports managers }}=$ 17.40, $\left.M_{\text {Future sports managers }}=16.00\right)$, but also for the total score of EI: $M_{\text {Current sports managers }}=$ 83.16 and $M_{\text {Future sports managers }}=79.12$. The effect size index (Hedge's g) reflects moderate to strong differences between the results. 
In the second stage of our research, we investigated whether there were significant differences between current and future sports managers in terms of temperamental characteristics (Table 3).

Table 3. Inferential statistics: current managers vs. future managers - Temperament

\begin{tabular}{lcccccccccccc}
\hline \multicolumn{1}{c}{ Type } & \multicolumn{1}{c}{ Skewness $<|\mathbf{1}|$} & \multicolumn{1}{c}{$\mathbf{F}$ test } & \multicolumn{4}{c}{$\mathbf{t}$ test - Equal variances } & \multicolumn{1}{c}{$\mathbf{t}$ test - Unequal variances } \\
\hline & $\mathbf{C}$ & $\mathbf{F M}$ & $\mathrm{F}$ & $\mathrm{F} \mathrm{critical}$ & $\mathbf{p}$ & $\mathbf{t}$ & $\mathbf{d f}$ & $\mathbf{g}$ & $\mathbf{p}$ & $\mathbf{t}$ & $\mathbf{d f}$ & $\mathbf{g}$ \\
IT & -0.56 & -0.12 & $1.79<1.98$ & 0.390 & -0.27 & 48 & 0.07 & & & & \\
IF & 0.29 & -0.27 & $0.90>0.50$ & & & & & 0.104 & -1.27 & 48 & 0.36 \\
IS & 0.08 & 0.40 & $1.28<1.98$ & 0.446 & -0.13 & 48 & 0.03 & & & & \\
IN & 0.31 & 0.005 & $1.41<1.98$ & 0.317 & -0.47 & 48 & 0.13 & & & & \\
ET & -0.57 & 0.02 & $1.25<1.98$ & 0.352 & 0.38 & 48 & 0.10 & & & & \\
EF & 0.53 & -0.10 & $0.62>0.52$ & & & & & 0.448 & -0.12 & 46 & 0.03 \\
ES & -0.29 & -0.70 & $0.505>0.504$ & & & & & 0.045 & 1.73 & 43 & 0.49 \\
EN & -0.76 & 0.15 & $0.72>0.50$ & & & & & 0.237 & 0.71 & 47 & 0.20 \\
INT & 0.39 & -0.08 & $1.20<1.98$ & 0.196 & -0.86 & 48 & & & & & 0.24 \\
EXT & -0.29 & 0.23 & $0.69>0.50$ & & & & & 0.217 & 0.78 & 46 & 0.22 \\
\hline
\end{tabular}

Note. C: Current sports managers; FM: Future sports managers; INT: Introversion; EXT: Extraversion.

Through the $t$ test for two independent samples, significant differences were highlighted between the two groups of participants in the case of extraverted sensing (sensation) temperament type. Experienced sports managers are more open, sociable and interpret information in a significantly different way compared to future sports managers $\left(M_{\text {Current sports }}\right.$ managers $=18.02 \pm 1.54, M_{\text {Future sports managers }}=17.12 \pm 2.16$ ). Specifically, managers in sports organizations rely significantly more, in the interpretation of information, on direct and concrete experiences, on the five senses (relating more strongly to external stimuli), and less on intuition (in which case, the interpretation of information occurs in the absence of concrete details). The effect size ( $\mathrm{g}$ ) reveals moderate differences between the results (for ES).

Following the results obtained in the case of the eight temperamental types, it can be seen that the strengths of current sports managers (temperamental types with the highest scores) are also the strengths of future sports managers: IT, ET, EF and ES. At the same time, the weak points (namely the temperamental types with the lowest scores) are the same for both groups: IF, IS, IN and EN. Figure 2 shows the differences between managers in terms of introversion and extraversion. 


\section{Current (blue) and future sports managers (orange) Introversion and Extraversion}

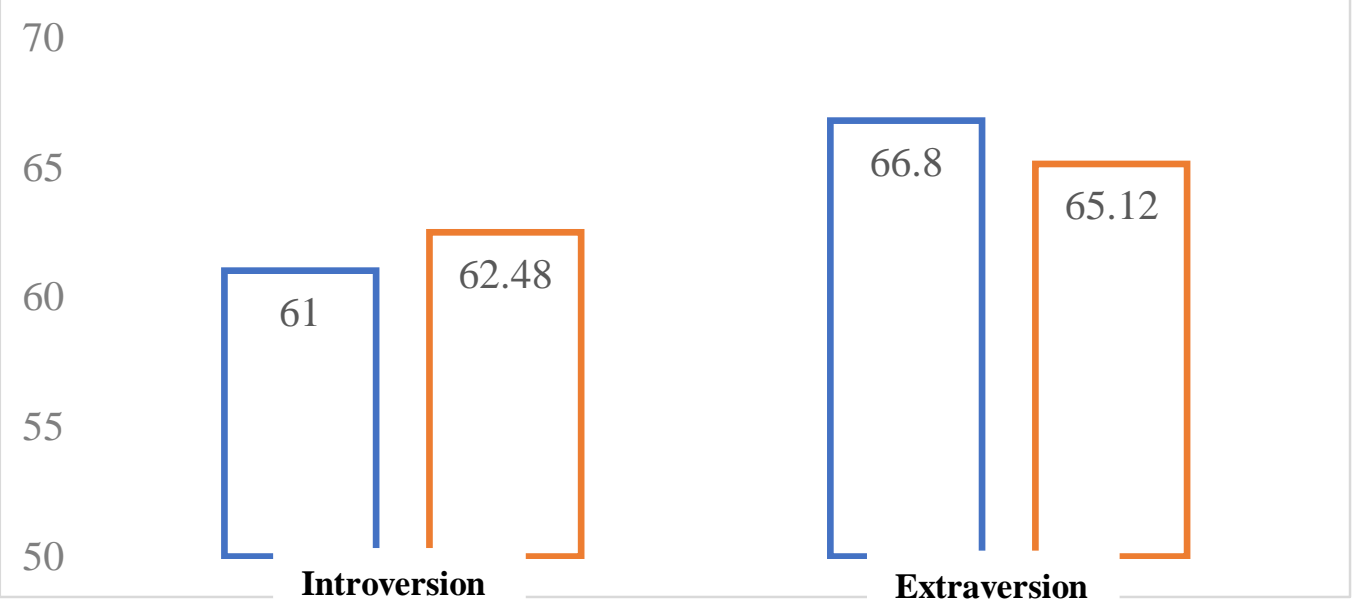

Figure 2. Current and future sports managers are more extravert than introvert

Highlighting that there were no statistically significant differences $(\mathrm{p}>0.05)$ between the two groups of participants (current and future sports managers) as regards introversion and extraversion, we checked whether such (significant) differences were still noticeable starting from the four psychological functions - sensation-intuition and thinking-feeling (Table 4).

Table 4. Inferential statistics - Psychological functions (sensation-intuition and thinkingfeeling)

\begin{tabular}{lccccccccccccc}
\hline \multicolumn{1}{c}{ PF } & \multicolumn{1}{c}{ Skewness $<|\mathbf{1}|$} & \multicolumn{2}{c}{ F test } & \multicolumn{4}{c}{ t test - Equal variances } & \multicolumn{4}{c}{ t test - Unequal variances } \\
\hline & $\mathbf{C}$ & $\mathbf{F M}$ & $\mathrm{F}$ & $\mathrm{F}$ critical & $\mathbf{p}$ & $\mathbf{t}$ & $\mathbf{d f}$ & $\mathbf{g}$ & $\mathbf{p}$ & $\mathbf{t}$ & $\mathbf{d f}$ & $\mathbf{g}$ \\
Thinking & -0.74 & 0.15 & $1.72<1.98$ & 0.471 & 0.07 & 48 & 0.02 & & & & \\
Feeling & 0.51 & -0.03 & $0.61>0.50$ & & & & & 0.191 & -0.86 & 45 & 0.24 \\
Sensation & 0.01 & -0.19 & $0.83>0.50$ & & & & & 0.197 & 0.87 & 48 & 0.24 \\
Intuition & 0.23 & 0.23 & $1.03<1.98$ & 0.367 & 0.34 & 48 & 0.09 & & & & \\
\hline
\end{tabular}

Note. PF: Psychological functions; C: Current sports managers; FM: Future sports managers.

Since the alpha significance threshold (p) is higher than 0.05 , we can conclude that, starting from the four psychological functions, there are no significant differences between the two groups of managers, which reflects that future sports managers match up well with the sports manager job in terms of the mentioned temperamental features.

\section{Discussion}

Along the time, researchers were interested to highlight the personality traits, feelings, the constellation of physical and mental states which play a significant role in obtaining tremendous performances at workplace, considering the sports field (we can think at athletes, coaches, sports managers etc. - see, for example Pelin et al., 2020). 
Data analysis and processing highlighted the existence of significant differences between the level of emotional intelligence of managers working in sports organizations and that of future sports managers. Current sports managers have a very high level of emotional intelligence, while future sports managers show a good level of EI. The literature emphasises the importance of emotional intelligence for sports managers (Lee \& Chelladurai, 2018; Chan \& Mallett, 2011) who have very good communication skills, are motivated and have wellestablished goals (Vasilescu \& Țifrea, 2020).

Sports managers use emotions so that they can achieve the proposed goals and build effective teams. In the sports context, emotional intelligence has been regarded as a key contributor to leadership (Chan \& Mallett, 2011). Specialised training is known to enhance the inter- and intrapersonal dimensions of emotional functioning. Therefore, it is essential for sports club managers to follow training programmes aimed at developing the others' but also their own ability to understand, perceive and regulate emotions in the workplace.

Statistical data processing has revealed that experienced sports managers are more open, sociable and interpret information in a significantly different way compared to future sports managers in terms of extraverted sensing (sensation) temperament type, which is specific to current managers. Regarding temperament, data analysis has highlighted that, starting from the four psychological functions (sensation-intuition and thinking-feeling) but also in the case of the two fundamental orientations (extraversion and introversion), there are no significant differences between the two groups (current and future managers). A good match of future sports managers with the job (considering the different temperamental characteristics) is emphasised. When talking about the two fundamental orientations mentioned above, it is noted that both current and future sports managers are more extravert than introvert (but the difference is not statistically significant).

After conducting a meta-analysis, Bono and Judge (2004) argued that extraversion was the best predictor variable of perceived transformational leadership, while Macra-Osorhean et al. (2011) asserted that Romanian sports managers showed a high level of sociability. However, Kahnweller (2009) claims that the most effective organization leaders are ambivert (oscillating between extraversion and introversion). Also, as Atamanik (2013) revealed, extraverts and introverts were equally effective as leaders in both corporate and academic environments, "indicating that introversion is not an obstacle to leadership performance in either competitive or nurturing environments" (p. 6). In this context, we also mention the study by Okafor et al. (2020), who emphasise that there is no significant correlation between temperament and the tendency to use prosocial strategies.

We consider that future sports managers have the temperamental characteristics required for a successful career in sport management. It is important for them to continue their efforts to develop those EI factors that can ensure greater efficiency in their future job, as well as the specific features of the ES temperamental type.

Future research is needed to complete the profile of the Romanian sports manager, by studying, for example, aspects such as: risk in sport - instrumental and stimulating risk (Makarowski et al., 2021a), aggression in sport - foul play, go-ahead and assertiveness (Makarowski et al., 2021b), different facets of anxiety, resilience, underlining the traits of sports managers by age, gender and country. 


\section{Conclusion}

Managers in sports organizations recognise and control their own emotions significantly better, are significantly more motivated (better mobilise their resources to achieve a goal) and (generally) have a significantly higher level of emotional intelligence compared to future sports managers. However, they are not significantly more empathetic and do not manage interpersonal relationships significantly better than future sports managers (a good match of future sports managers with the job is highlighted, considering empathy and interpersonal relationship management).

Experienced sports managers rely significantly more, in the interpretation of information, on direct and concrete experiences, on the five senses (relating more strongly to external stimuli), and less on intuition (in which case, the interpretation of information occurs in the absence of concrete details).

The findings of our study provide future sports managers with valuable information about emotional intelligence factors (recognition of one's emotions, control, intelligent manipulation of emotions, inner motivation and productive use of emotions) and temperamental characteristics specific to experienced managers (ES temperamental type), which facilitates the process of personal and professional development.

\section{References}

Atamanik, C. (2013). The introverted leader: Examining the role of personality and environment. Center for Leadership Current Research. Paper 2, 1-9.

https://core.ac.uk/download/pdf/46948159.pdf

Ayman, R., Korabik, K., \& Morris, S. (2009). Is transformational leadership always perceived as effective? Male subordinates' devaluation of female transformational leaders. Journal of Applied Social Psychology, 39(4), 852-879. https://doi.org/10.1111/J.1559-1816.2009.00463.X

Barros, C. P., \& Lucas, J. (2001). Sports managers and subsidies. European Sport Management Quarterly, 1(2), 112-123. http://dx.doi.org/10.1080/16184740108721891

Bono, J. E., \& Judge, T. A. (2004). Personality and transformational and transactional leadership: A meta-analysis. Journal of Applied Psychology, 89(5), 901-910. https://doi.org/10.1037/0021-9010.89.5.901

Chan, J. T., \& Mallett, C. J. (2011). The value of emotional intelligence for high performance coaching. International Journal of Sports Science and Coaching, 6(3), 315-328. https://doi.org/10.1260/1747-9541.6.3.315

Chopra, P. K., \& Kanji, G. K. (2010). Emotional intelligence: A catalyst for inspirational leadership and management excellence. Total Quality Management \& Business Excellence, 21(10), 971-1004. https://doi.org/10.1080/14783363.2010.487704

Dumitru, E. S. (2021). Studiu privind inteligența emoțională, temperamentul și stilul de conducere al managerilor din organizațiile sportive (Teză de disertație nepublicată) [Study on the emotional intelligence, temperament and leadership style of managers in sports organizations (Unpublished dissertation thesis)]. UNEFS București.

Gatjens-Reuter, M., \& Behrens, C. (1999). Manual de secretariat şi asistență managerială [Secretarial and managerial assistance manual]. Editura Tehnică.

Girginov, V., Papadimitriou, D., \& de D’Amico, R. L. (2006). Cultural orientations of sport managers. European Sport Management Quarterly, 6(1), 35-66. 
https://doi.org/10.1080/16184740600798347

Hacker, C. A. (2003). Maintaining positive relationships when giving and receiving critical feedback. Information Systems Management, 20(4), 77-79. https://doi.org/10.1201/1078/43647.20.4.20030901/77296.11

Hoekman, R., Elling, A., \& van der Poel, H. (2019). Local policymaking in sport: Sport managers' perspectives on work processes and impact. Journal of Global Sport Management, 1-23. https://doi.org/10.1080/24704067.2018.1537682

Horch, H. D., \& Schütte, N. (2003). Competencies of sport managers in German sport clubs and sport federations. Managing Leisure, 8(2), 70-84. http://dx.doi.org/10.1080/1360671032000085684

Ibrahim, L. Y. (2016). Effective managerial leadership and challenges in sport organization. Journal of Sports and Physical Education, 3(5), 73-80. DOI: 10.9790/6737-0304XXXX

Joyce, D. (2010). Essentials of temperament assessment. John Wiley \& Sons.

Koca, C., \& Öztürk, P. (2015). Gendered perceptions about female managers in Turkish sport organizations. European Sport Management Quarterly, 15(3), 381-406. http://dx.doi.org/10.1080/16184742.2015.1040046

Lee, Y. H., \& Chelladurai, P. (2018). Emotional intelligence, emotional labor, coach burnout, job satisfaction, and turnover intention in sport leadership. European Sport Management Quarterly, 18(4), 393-412. https://doi.org/10.1080/16184742.2017.1406971

Macra-Osorhean, M., Lupu, I., Bogdan, T., \& Lazăr, L.C. (2011). Psychological profile of Romanian sports manager in an international comparative perspective. Studia UBB Educatio Artis Gymnasticae, 56(4), 19-30.

Makarowski, R., Piotrowski, A., Predoiu, R., Görner, K., Predoiu, A., Mitrache, G., Malinauskas, R., Vicente-Salar, N., Vazne, Z., Cherepov, E., Miklósi, M., Kovács, K., Pelin, R., Boe, O., Rawat, S., Deshpande, A., Plopa, M., \& Plopa, W. (2021a). The English-speaking, Hungarian, Latvian, Lithuanian, Romanian, Russian, Slovak, and Spanish adaptations of Makarowski's Stimulating and Instrumental Risk Questionnaire for martial arts athletes. Archives of Budo, 17, 1-33. WOS: 000663516800001

Makarowski, R., Piotrowski, A., Görner, K., Predoiu, R., Predoiu, A., Mitrache, G., Malinauskas, R., Vicente-Salar, N., Vazne, Z., Bochaver, K., Cherepov, E., Hamzah, I., Nikkhah-Farkhani, Z., Miklósi, M., Kovács, K., Pelin, F., Boe, O., Rawat, S., Deshpande, A., \& Plopa, M. (2021b). The Hungarian, Latvian, Lithuanian, Polish, Romanian, Russian, Slovak, and Spanish, adaptation of the Makarowski's Aggression Questionnaire for martial arts athletes. Archives of Budo, 17, 75-108. WOS: 000663526100001

Martell, R. F., Parker, C., Emrich, C. G., \& Crawford, M. (1998). Sex stereotyping in the executive suite: "Much ado about something". Journal of Social Behavior and Personality, 13(1), 127-138. WOS: 000074376000010

Messner, M. A. (2002). Taking the field: Women, men, and sports. University of Minnesota Press.

Mitrache, G., \& Predoiu, R. (2016). Psihopedagogie - Curs în tehnologia IFR. [Psychopedagogy - Course in IFR technology] (Ediție revizuită). Discobolul.

Minulescu, M. (2012). Temperamentul școlarilor. Dialogul temperamentelor: Profesor și elev: Modulul I - Inițiere [The temperament of schoolchildren. Temperament dialogue: Teacher and student: Module I - Initiation]. Comunicare.ro

Mostafa, M. M. (2003). Attitudes towards women who work in Egypt. Women in Management Review, 18(5), 252-266. https://doi.org/10.1108/09649420310485096

Okafor, B. E., Yakubova, M. M., \& Kingsley Westermann, C. Y. (2020). Manager-employee communication: The influence of temperament and leader-member exchange quality on 
employees' use of upward dissent strategies. Western Journal of Communication, 85(3), 400-426. https://doi.org/10.1080/10570314.2020.1850850

Pearson, A., \& Weinberg, A. (2017). The impact of counsellor training on emotional intelligence. British Journal of Guidance \& Counselling, 45(5), 610-621. https://doi.org/10.1080/03069885.2016.1226496

Pelin, F., Predoiu, R., Mitrache, G., \& Predoiu, A. (2020). Mental features of top level athletes. Discobolul - Physical Education, Sport and Kinetotherapy Journal, 59(1), 5-14. https://doi.org/10.35189/dpeskj.2020.59.1.1

Pelin, F., Predoiu, R., Mitrache, G., Predoiu, A., \& Grigore, V. (2018). Generation of efficient behaviours in the case of performance athletes. Discobolul - Physical Education, Sport and Kinetotherapy Journal, 53, 31-38.

Predoiu, R., Makarowski, R., Görner, K., Bota, A., Predoiu, A., Mitrache, G., \& Grigore, V. (2020). Key personality traits of martial arts and world's top coaches - impact on future martial arts specialists. Archives of Budo, 16, 129-142. WOS: 000579413000001

Schein, V. E. (2007). Women in management: Reflections and projections. Women in Management Review, 22(1), 6-18. https://doi.org/10.1108/09649420710726193

Soucie, D. (1994). The emergence of sport management as a professional occupation: A North American perspective. European Journal for Sport Management, 1(2), 13-30.

Stănescu, M., Vasile, L., \& Stănescu, R. (2016). Study about the psychological profile of the future sport managers. European Proceedings of Social and Behavioural Sciences, 15, 935-942. https://doi.org/10.15405/EPSBS.2016.09.116

Stoker, J. I., van der Velde, M. V. D, \& Lammers, J. (2012). Factors relating to managerial stereotypes: The role of gender of the employee and the manager and management gender ratio. Journal of Business and Psychology, 27(1), 31-42. https://doi.org/10.1007/s10869-011-9210-0

Teodorescu, S., \& Urzeală, C. (2013). Management tools in sports performance. Procedia Social and Behavioral Sciences, 81, 84-88. https://doi.org/10.1016/j.sbspro.2013.06.392

Vasilescu, F., \& T,ifrea, C. (2020). Optimisation of management activity in sports organizations. Discobolul - Physical Education, Sport and Kinetotherapy Journal, 59(Supplementary Issue), 565-580. https://doi.org/10.35189/dpeskj.2020.59.s.8

Vrooman, J. (2000). The economics of American sports leagues. Scottish Journal of Political Economy, 47(4), 364-398. DOI: 10.1111/1467-9485.00169 